\title{
Levels of protected lysine and methionine in the diet of lambs: nutritional parameters and protein metabolites
}

\section{Níveis de lisina e metionina protegidas na ração de borregas: parâmetros nutricionais e metabólitos proteicos}

\author{
Carolina Moreira Araújo ${ }^{1 *}$; Gilberto de Lima Macedo Junior²; Karla Alves \\ Oliveira $^{1}$; Adriana Lima Silva ${ }^{3}$; Marco Túlio Santos Siqueira ${ }^{3}$
}

\begin{abstract}
The objective of this study was to evaluate the effect of inclusion of different levels of protected lysine and methionine on the nutritional parameters and protein metabolites of lambs. The experiment was carried out at the Capim Branco Experimental Farm, at Uberlândia Federal University, during the months of September and October 2016. Five blood lambs $1 / 2$ Dorper $\times 1 / 2$ Santa Inês, approximately eight months old and with an average weight of $50 \mathrm{~kg}$, were distributed in a Latin square scheme $5 \times$ 5 (five treatments and five replicates). The treatments consisted of the inclusion in the diet of different levels of lysine and methionine protected from ruminal degradation (MicroPEARLS LM ${ }^{\circledR}$ ): $0 \mathrm{~g}, 8 \mathrm{~g}$, $16 \mathrm{~g}, 24 \mathrm{~g}$, and $32 \mathrm{~g}$. The diet was composed of corn silage and concentrate in a ratio of 30V:70C. The experiment was divided into five phases. Each phase had a duration of fifteen days (ten days of adaptation of the animals to the experimental diets and five days of data collection). The animals were kept in individual metabolic cages. A digestibility assay was performed to determine the apparent dry matter intake and digestibility (DMI/DDMI), nitrogen balance, and protein metabolites. The DMI (kg day $^{-1}$ ) and in relation to the metabolic weight presented a positive linear equation, and was highest for the treatment with $32 \mathrm{~g}$ of amino acids, as well as the ingested nitrogen and nitrogen balance, being positive in all treatments. There was no difference $(\mathrm{P}>0.05)$ in the DDMI. The crude protein and urea concentrations remained above the recommended levels and the concentration of creatinine remained below the recommended level. The inclusion of protected amino acids up to $32 \mathrm{~g}$ increases DMI and urinary nitrogen excretion without negatively affecting digestibility. The protein metabolism was altered, without causing damage to the performance of the animals.
\end{abstract}

Key words: Nitrogen. Sheep. Protein. Ruminants. Urea.

\section{Resumo}

O objetivo deste trabalho foi avaliar a inclusão de níveis de lisina e metionina protegidos, sobre os parâmetros nutricionais e metabólitos proteicos de borregas em crescimento. O experimento foi realizado na Fazenda Experimental Capim Branco, da Universidade Federal de Uberlândia, durante os meses de setembro e outubro de 2016. Utilizou-se cinco borregas $1 / 2$ sangue Dorper x $1 / 2$ Santa Inês, com aproximadamente oito meses de idade e peso médio de $50 \pm 5 \mathrm{~kg}$, distribuídas em esquema quadrado

\footnotetext{
1 Discentes, Curso de Doutorado, Programa de Pós-Graduação em Ciências Veterinárias, Universidade Federal de Uberlândia, UFU, Uberlândia, MG, Brasil. E-mail: carolina.am@hotmail.com; karla.alves.oliveira@hotmail.com

2 Prof. Dr., Universidade Federal de Uberlândia, UFU, Faculdade de Medicina Veterinária, Programa de Pós-Graduação em Ciências Veterinárias, Uberlândia, MG, Brasil. E-mail: gilbertomacedojr@gmail.com

3 Discentes, Curso de Graduação em Zootecnia, UFU, Uberlândia, MG, Brasil. E-mail: adrianalimasilva95@gmail.com; marcotulio.s.siqueira@gmail.com
}

* Author for correspondence 
latino $5 \times 5$ (cinco tratamentos e cinco repetições). Os tratamentos consistiram na inclusão de diferentes

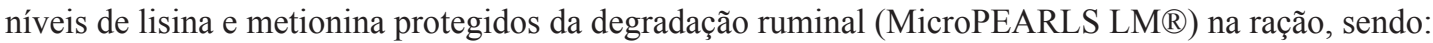
$0 \mathrm{~g}, 8 \mathrm{~g}, 16 \mathrm{~g}, 24 \mathrm{~g}$ e $32 \mathrm{~g}$. A dieta era composta por silagem de milho e concentrado na relação 30V:70C. $\mathrm{O}$ experimento foi divido em cinco fases. Cada fase teve duração de quinze dias (dez dias de adaptação dos animais e cinco de coleta de dados). Os animais foram mantidos em gaiola metabólicas individuais. Realizou-se um ensaio de digestibilidade para determinar o consumo e digestibilidade aparente da matéria seca (CMS/DGMS), balanço de nitrogênio e metabólitos proteicos. O CMS (kg dia -1) e em relação ao peso metabólico apresentaram equação linear positiva, assim como o nitrogênio ingerido e balanço de nitrogênio, sendo positivo em todos tratamentos. Não houve diferença $(\mathrm{P}>0,05)$ para digestibilidade da MS. As concentrações de proteína bruta e ureia mantiveram-se acima do recomendado, enquanto creatinina, manteve-se abaixo. A inclusão de aminoácidos protegidos até $32 \mathrm{~g}$ aumenta o CMS e excreção de nitrogênio urinário, sem afetar negativamente a digestibilidade. O metabolismo proteico foi alterado, sem causar danos ao desempenho dos animais.

Palavras-chave: Nitrogênio. Ovinos. Proteína. Ruminantes. Ureia.

\section{Introduction}

The interaction between sources of degraded and non-degraded protein in the rumen makes it possible to increase the flow of protein that reaches the small intestine and, consequently, can increase the productivity of ruminants. The more similar the profile of the essential amino acids available for absorption in the small intestine to the animal's requirement, the higher the efficiency of the use of amino acids for protein synthesis (NRC, 2007).

Protein degradation is responsible for the energy supply obtained by the animal in the small intestine (BERCHIELLI et al., 2006), therefore, the inclusion of protein in the diet can result in increases in consumption due to the higher energy source readily available to the animal.

Protecting amino acids from ruminal degradation is necessary, since when supplied without going through the encapsulation processes, they are rapidly degraded by ruminal microorganisms and do not meet the demand for metabolisable protein.

The higher efficiency of the use of metabolisable protein when the diet is balanced in lysine and methionine reduces nitrogen excretion and consequently reduces the energy expenditure involved in this process. In addition, the increased availability of methionine might have positive effects on the hepatic metabolism of the animal, such as reducing the incidence of fatty liver in dairy cows, since it is a component of low density lipoprotein (VLDL) (SCHWAB et al., 2007). The combination of these two aspects might reduce the risk of ketosis in ruminants (SANTOS et al., 2017).

Metabolic variations are not caused exclusively by the excess or lack of an isolated nutrient since there is an interrelationship between them, which can lead to errors in interpretation if nutrients are analysed in isolation. A good example is the concentration of blood urea. This depends directly on the contribution of degradable proteins present in the diet, thus representing the protein metabolic pathway. However, the energy supply can also influence the concentration. When the consumption of energy from the diet is not sufficient, a change occurs in the metabolism of the ruminal microorganisms, promoting an increase in the ammonia concentration and, consequently, an increase in blood urea (CONTRERAS et al., 2000). It might also be a response to the inclusion of protected amino acids.

The objective of this study was to evaluate the influence of inclusion of different levels of protected amino acids (lysine and methionine) in lambs' diets on nutritional parameters and protein metabolism. 


\section{Material and Methods}

The experiment was conducted at the Experimental White Grass Farm, belonging to the Faculty of Veterinary Medicine of the Federal University of Uberlândia (UFU), in Uberlândia, MG, from September to October 2016. The experiment was submitted to an analysis by the Ethics Committee on the use of animals (CEUA) and obtained approval under protocol number $128 / 16$.

Five $1 / 2$ Dorper $\times 1 / 2$ Santa Inês lambs were used at approximately eight months of age, with an average weight of $50 \mathrm{~kg}$. The ewes were vermifugated before the start of the experimental period with oral monepantel ( $1 \mathrm{~mL} 10 \mathrm{~kg}^{-1}$ body weight). The animals were kept in individual metabolic cages with slatted wood that contained a feeder, drinker, and salt shaker. The cages were kept in a cementfloored shed and covered by clay tiles, with lateral ventilation, and were protected from direct solar radiation.

The treatments were randomly selected and consisted of the inclusion of different amounts of MicroPEARLS LM ${ }^{\circledR}(0 \mathrm{~g}, 8 \mathrm{~g}, 16 \mathrm{~g}, 24 \mathrm{~g}$, and $32 \mathrm{~g})$, which was the encapsulated amino acid supplement (lysine and methionine) (Table 1). The ration was balanced according to the NRC (2007) for gains of $250 \mathrm{~g} \mathrm{day}^{-1}$ for the animal category of the present study. It was composed of corn silage and concentrate in the ratio 70:30 (Table 1).

Table 1. Chemical and bromatological composition (\%) of concentrate and corn silage.

\begin{tabular}{ccccc}
\hline Ingredients & Concentrate & Corn silage & MicroPEARLS LM $^{\otimes^{*}}$ & Total ration \\
\hline Crushed corn & $60.5^{* *}$ & - & - & - \\
Soybean meal & $36.0^{* *}$ & - & - & - \\
Urea & $1.0^{* *}$ & - & - & - \\
Mineral salt & $2.5^{* *}$ & - & - & $72.8^{* *}$ \\
\hline DM & $90.2^{* *}$ & $32.2^{* *}$ & $99.0^{*}$ & $19.36^{* *}$ \\
CP & $24.9^{* *}$ & $6.3^{* *}$ & $43.75^{*}$ & $33.74^{* *}$ \\
NDF & $24.8^{* *}$ & $54.6^{* *}$ & - & $14.68^{* *}$ \\
NDA & $7.0^{* *}$ & $32.6^{* *}$ & - & - \\
EE & - & - & $48.65^{*}$ & - \\
\hline
\end{tabular}

*Information provided by the manufacturer; MicroPearls LM: 75\% lysine and 25\% methionine. **Information obtained from the analyses performed at the animal nutrition laboratory of UFU and the Federal Institute of Uberaba. MS: dry matter, CP: crude protein, NDF: neutral detergent fibre, FDA: acid detergent fibre, and EE: ethereal extract.

The experiment lasted 75 days and was divided into five phases. Each phase had a duration of 15 days, 10 days for the adaptation of the animals to the experimental diet and 5 days for the collection of samples.

The food was supplied daily at $08 \mathrm{~h} 00$ and $16 \mathrm{~h} 00$, with $50 \%$ of the total at each meal. The amino acids were supplied integrally in the morning meal by manually mixing the food directly in the trough. The amount of amino acids was weighed using a precision digital scale of $0.0001 \mathrm{~g}\left(\right.$ Shimadzu $^{\circledR}$, model UX420H). Each day, the quantities offered and the leftovers were weighed using a Filizola ${ }^{\circledR}$ electronic scale model CS-15 with a precision of $5 \mathrm{~g}$ to monitor the consumption by the animals. The rations were provided so that there was more than $10 \%$ of the total leftover. Food leftovers were collected and stored in properly identified plastic bags and kept in a freezer at $-10{ }^{\circ} \mathrm{C}$. After the collection period, the samples were homogenised individually and a representative aliquot was separated for bromatological analyses. 
Below the metabolic cages, an artefact was maintained that allowed faecal separation to enable an evaluation of digestibility. To harvest all the faeces, the cages were cleaned every day in the morning with the aid of a spatula and a broom. The faeces were weighed and homogenised, and a representative aliquot of the sample was collected once every day in the morning. The aliquots were conditioned in plastic bags, identified, and kept in a freezer at $-100^{\circ} \mathrm{C}$.

Subsequently, the pre-drying of samples of leftovers and faeces in a forced circulation oven at $55{ }^{\circ} \mathrm{C}$ for 72 hours was carried out until a constant weight was obtained. The samples were then milled with Willey-type knives equipped with $1 \mathrm{~mm}$ diameter sieves. After that, the samples were taken to the laboratory where the dry matter analysis of the samples of leftovers and faeces were carried out in an oven at $105{ }^{\circ} \mathrm{C}$ for 24 hours. Following this, it was possible to calculate the final dry matter and nutrient content of the samples, and the apparent digestibility using the following formulas (MAYNARD et al., 1984):

$$
\mathrm{CN}=(\text { Cons } \times \% \text { Cons })-(\text { Under } \times \% \text { Under })
$$

Where:

$\mathrm{CN}=$ nutrient consumption $(\mathrm{kg})$, Cons $=$ amount of food consumed $(\mathrm{kg}), \%$ Cons $=$ nutrient content in food supplied (\%), Under = amount of leftover withdrawal $(\mathrm{kg})$, and $\%$ Under = nutrient content in leftovers $(\%)$.

$$
\mathrm{A}=(\mathrm{CN}-(\mathrm{Fez} \times \% \mathrm{Fez})) /(\mathrm{CN} \times 100)
$$

Where:

$\mathrm{DA}=$ apparent digestibility $(\%), \mathrm{Fez}=$ amount of faeces collected $(\mathrm{kg}), \% \mathrm{Fez}=$ nutrient content in faeces $(\%)$, and $\mathrm{CN}=$ nutrient consumption $(\mathrm{kg})$.

The crude protein content (PB) was determined according to the methodologies described by Silva and Queiroz (2002) and the dry matter consumption (DMI) was determined by the difference between the supply and leftovers.
The urine $\mathrm{N}$ content was calculated using the Kjeldahl method (SILVA; QUEIROZ, 2002). The amount of acid used in the titration is used to calculate the $\mathrm{N}$ content of the sample, using the formula:

$$
\% \mathrm{~N}=(\mathrm{V} \times \mathrm{FC} \times \mathrm{N} \times 0.014) / \mathrm{P} \times 100
$$

Where:

$\mathrm{V}=$ volume of $0.1 \mathrm{~N} \mathrm{HCl}$ used in the titration, $\mathrm{FC}$ = correction factor of $0.1 \mathrm{~N} \mathrm{HCl}, \mathrm{N}=$ normality of the acid used in the titration, $0.014=$ milliequivalentgram of nitrogen, and $\mathrm{P}=$ weight of the sample in grams.

The balance of $\mathrm{N}$, or nitrogen retained, was calculated using the formula proposed by Zeoula et al. (2006):

$\mathrm{NB}=(\mathrm{N}$ provided $\mathrm{g}-\mathrm{N}$ of leftovers $\mathrm{g})-(\mathrm{N}$ in faeces $\mathrm{g}+\mathrm{N}$ in urine $\mathrm{g}$ )

Consequently, the consumption of $\mathrm{N}(\mathrm{CN})$ and the relationship between $\mathrm{N}$ retained and ingested $\mathrm{N}$ (NR NI) were calculated using the formulas:

$$
\mathrm{CN}=\mathrm{N} \text { provided }(\mathrm{g})-\mathrm{N} \text { of leftovers }(\mathrm{g})
$$

$$
\mathrm{NR} \text { IN }=\mathrm{NB} / \mathrm{CN}
$$

For the biochemical analysis of the blood, a daily collection was performed in the morning, before the first feeding, on three alternate days of the evaluation, totalling three collections per phase. Blood samples were collected for the evaluation of biochemical components by jugular venipuncture using Vacutainer ${ }^{\circledR}$ tubes without anti-coagulant. The blood samples collected were centrifuged at $3000 \mathrm{rpm}$ for 10 minutes, the sera were separated into aliquots, stored in microtubes, and stored in a freezer at $-5{ }^{\circ} \mathrm{C}$ for further laboratory analyses. All samples were processed in an automated biochemical analyser (Bioplus ${ }^{\circledR}$ 2000) using a commercial kit from Biotécnica ${ }^{\circledR}$. The results used for discussion were obtained from the average of the three collections in each phase.

The biochemical components for the determination of protein metabolism were: total 
protein (TP), albumin (ALB), creatinine (CREAT), uric acid (AU), globulin (GLUB) (obtained by subtraction of PT by ALB), and urea.

The design was a $5 \times 5$ Latin square, with five treatments and five replications. The averages of all data were submitted to analysis by a regression study at $5 \%$ probability. All the variables had their normality and homogeneity tested.

\section{Results and Discussion}

The intake of dry matter and body weight showed a positive linear response (Table 2), that is, the higher the level of inclusion of protected amino acids in the diet, the higher the consumption, with a difference of $16.94 \%$ between the lowest and highest consumption ( $0 \mathrm{~g}$ and $32 \mathrm{~g}$ ). According to the NRC (2007), it is recommended that lambs in this category consume $1.39 \mathrm{~kg} \mathrm{MS} \mathrm{day}^{-1}$, thus, animals receiving $32 \mathrm{~g}$ of protected amino acids presented a consumption $3.59 \%$ above that recommended, whereas those that did not receive the amino acids (control, $0 \mathrm{~g}$ amino acids) consumed $13.95 \%$ less than the recommended level. The dry matter intake in relation to body weight (DMI $\mathrm{BW}^{-1}$ ) was lower than that recommended by the NRC (2007), which is $2.78 \%$. This reduction of $11 \%$ in $\mathrm{DMI} \mathrm{BW}^{-1}$ might be due to the committee's recommendations being based on animals genetically different from those used in the present study.

Table 2. Dry matter intake (DMI) in relation to metabolic weight (DMI MW) and body weight (DMI BW) and dry matter digestibility of ewes receiving rations with different levels of protected amino acids.

\begin{tabular}{ccccc}
\hline Amino acid level & DMI $^{1}\left(\mathrm{~kg} \mathrm{day}^{-1}\right)$ & $\mathrm{DMI} \mathrm{MW}^{2}\left(\mathrm{~kg} \mathrm{day}^{-1}\right)$ & $\mathrm{DMI} \mathrm{BW}^{3}(\%)$ & $\mathrm{DMD}$ \\
\hline $0 \mathrm{~g}$ & 1.196 & 60.23 & 2.22 & 79.42 \\
$8 \mathrm{~g}$ & 1.328 & 67.17 & 2.48 & 82.26 \\
$16 \mathrm{~g}$ & 1.324 & 67.35 & 2.49 & 80.78 \\
$24 \mathrm{~g}$ & 1.294 & 65.54 & 2.43 & 78.96 \\
$32 \mathrm{~g}$ & 1.440 & 73.96 & 2.74 & 81.77 \\
\hline Mean & 1.31 & 66.78 & 2.47 & 80.64 \\
$\mathrm{Cv}$ & 8.07 & 8.28 & 8.47 & 3.02 \\
\hline
\end{tabular}

*MicroPearls LM: 75\% lysine and 25\% methionine; $\mathrm{CV}$ - Coeficient of variation; ${ }^{1} \hat{\mathrm{Y}}=1,225600+0,005675 \mathrm{x}, \mathrm{R} 2=67,65 \% ; 2 \hat{\mathrm{Y}}$ $=61,74400+0,315925 x, R 2=68,99 \% ; 3 \hat{Y}=2,28280+0,01210 x, R^{2}=69,98 \%$.

The highest level of protected amino acids in the diet might have provided better compliance with the metabolisable protein requirements of lambs, and the ingredients used in the concentrate (soybean meal, maize, silage and urea, Table 1) served as a source of rumen degradable protein (PDR), therefore maximising the synthesis of microbial protein, since the synthesis of microbial protein is dependent on the concentration and quality of energy sources and dietary nitrogen in the rumen (RIBEIRO et al., 2001). This balance between the sources of protein might have caused an increase in the consumption of dry matter.

The energy supply that reaches the intestine of the animal comes mainly from the digestion of protein, carbohydrate, and long chain fatty acids (BERCHIELLI et al., 2006). Therefore, the protected amino acids might have promoted a high energy supply to the small intestine, allowing the energy to be used for growth, increasing the consumption by the animals. Since the diet provided was highly palatable, consumption was once again benefited. 
According to Alves (2004), when the metabolisable protein is high quality, that is, rich and with an adequate essential amino acid profile, the crude protein content of the feed can be reduced, the efficiency of use of the metabolisable protein is optimised, the excretion of urea and other nitrogen compounds is reduced (lower energy expenditure), and animal performance is maximised. Antongiovanni et al. (2002) did not observe improvements in dry matter intake with the addition of protected methionine and lysine in the diet of lambs at two months of age.

In diets with digestibility values lower than $66 \%$, food intake is determined by physical factors, i.e. it is related to the physical distention of the rumenreticulum. Already in diets with digestibility values higher than $66 \%$, physiological factors control the food intake, i.e. the energy or nutritional balance of the diet (MERTENS, 1994). In the present study, the average dry matter digestibility (DMS) was 80.64 and did not present a difference between treatments. The high digestibility observed might be because $70 \%$ of the diet was composed of concentrate which is highly fermentable in the rumen.

According to the NRC (1985), microbial growth is dependent on the relationship between particle size, volume, and feed rate of the rumen, and an increase in the rate of passage reduces the average age of the microbial population due to the removal of mature organisms, and consequently reduces the energy demand of the microbiota. Thus, there is higher efficiency of the use of system energy for microbial growth (POLAN, 1988). The digestibility remained high in all treatments, despite the change observed in DMI (Table 2), indicating that the high energy intake of the diet promoted an increase in microbial growth and passage rate. In addition, the concentrate contained urea (Table 1), and this nitrogen source is readily degraded in the rumen and is used in the formation of microbial proteins. Han et al. (1996) evaluated a diet with and without the inclusion of protected lysine and methionine for sheep with a mean weight of $50 \mathrm{~kg}$ and observed a higher DMS with the inclusion of amino acids, from $69.4 \pm 1.75$ to $72.6 \pm 2.20 \%$.

The nitrogen balance is indicative of protein metabolism and is an important parameter in the evaluation of food, since it enables an assessment of whether the animal is in equilibrium regards to its nitrogen compounds (GUIMARÃES JÚNIOR et al., 2007). The values found for ingested $\mathrm{N}$ presented a positive linear equation (Table 3 ). In the present study, the animals ingested on average 3\% of $\mathrm{N} \mathrm{DMI}^{-1}$. This nitrogen intake in the present study is related to the increase in DMI (Table 2) and to the increase in the inclusion level of the supplemental protected amino acids in the concentrate. Moreno et al. (2010) observed a $\mathrm{N}$ intake of $32.60 \mathrm{~g}$ day $^{-1}$ for sheep fed with $60 \%$ concentrate containing $19.0 \%$ CP. Geron et al. (2015) found values of $12.38 \mathrm{~g}$ day ${ }^{1}$ working with $40 \%$ concentrate containing $13.0 \%$ PB.

Since there was no difference $(\mathrm{P}>0.05)$ in $\mathrm{DMS}$, the increase in $\mathrm{N}$ intake also did not influence faecal and urinary $\mathrm{N}$ excretion (Table 3 ). The faecal $\mathrm{N}$ losses corresponded to $15.32 \%$ of the total ingested $\mathrm{N}$. The high values of DMS (Table 2) indicate a better use of ingested $\mathrm{N}$ and decreased excretion via faeces. The excretion of $\mathrm{N}$ in the faeces indicates that a higher conservation of nitrogenous compounds occurs when diets with lower protein content are used, since the increase in CP in the diet can cause excess urea release (Table 4), via urine, constituting protein waste. 
Table 3. Nitrogen ingested ( $\mathrm{N}$ ingested), faecal nitrogen ( $\mathrm{N}$ Faecal), urinary nitrogen ( $\mathrm{N}$ urinary), nitrogen balance (NB), and the relationship between nitrogen retained and ingested (NR IN) as a function of the treatments. Values are expressed in g animal $^{-1}$ day $^{-1}$, except for (NR IN).

\begin{tabular}{cccccc}
\hline Amino acid level $^{*}$ & $\mathrm{~N}_{\text {ingested }}{ }^{1}$ & $\mathrm{~N}$ faecal & $\mathrm{N}$ urinary & NB $^{2}$ & NR IN \\
\hline $0 \mathrm{~g}$ & 33.26 & 6.01 & 8.87 & 17.68 & 0.53 \\
$8 \mathrm{~g}$ & 41.70 & 6.26 & 8.87 & 25.14 & 0.62 \\
$16 \mathrm{~g}$ & 42.32 & 6.29 & 8.48 & 27.23 & 0.67 \\
$24 \mathrm{~g}$ & 41.13 & 6.34 & 9.87 & 23.41 & 0.61 \\
$32 \mathrm{~g}$ & 47.48 & 6.66 & 8.33 & 30.52 & 0.67 \\
\hline Mean & 41.18 & 6.31 & 8.89 & 24.79 & 0.62 \\
$\mathrm{CV}$ & 11.19 & 16.65 & 30.09 & 26.87 & 16.47 \\
\hline
\end{tabular}

*MicroPearls LM: 75\% lysine and 25\% methionine; CV - Coeficient of variation; ${ }^{1} \hat{\mathrm{Y}}=135,60440+0,348475 \mathrm{x}, \mathrm{R}^{2}=74,73 \%{ }^{2}$ $\hat{\mathrm{Y}}=20,00840+0,299325 x, R^{2}=62,74 \%$.

Table 4. Effect of different levels of protected lysine and methionine in the diet of growing lambs on protein metabolism.

\begin{tabular}{ccccccc}
\hline Amino acid level* & TP & Alb. & Creat. & UA. & Glob. & Urea \\
\hline $0 \mathrm{~g}$ & 7.07 & 2.92 & 0.71 & 0.38 & 4.14 & 46.73 \\
$8 \mathrm{~g}$ & 7.01 & 2.77 & 0.65 & 0.39 & 4.24 & 43.93 \\
$16 \mathrm{~g}$ & 7.09 & 3.08 & 0.63 & 0.34 & 4.01 & 42.66 \\
$24 \mathrm{~g}$ & 7.16 & 2.79 & 0.54 & 0.35 & 4.37 & 49.93 \\
$32 \mathrm{~g}$ & 6.91 & 3.11 & 0.65 & 0.35 & 3.79 & 44.12 \\
\hline Mean & 7.05 & 2.93 & 0.63 & 0.36 & 4.11 & 45.47 \\
$\mathrm{CV}$ & 13.20 & 29.94 & 18.72 & 18.81 & 24.82 & 17.65 \\
VR $^{* *}$ & $6.0-7.9$ & $2.4-3.0$ & $1.2-1.9$ & $0-1.9$ & $3.5-5.7$ & $17.1-42.8$ \\
\hline
\end{tabular}

*MicroPearls LM: 75\% lysine and 25\% methionine; TP: total protein (mg dL $\left.{ }^{-1}\right)$, Alb.: albumin (mg dL $\left.\mathrm{m}^{-1}\right)$, Creat.: creatinine (mg $\left.\mathrm{dL}^{-1}\right)$, UA.: uric acid $\left(\mathrm{mg} \mathrm{dL}^{-1}\right)$, Glob.: globulin $\left(\mathrm{g} \mathrm{dL}^{-1}\right)$, urea $\left(\mathrm{mg} \mathrm{dL}^{-1}\right), \mathrm{CV}$ : coefficient of variation, and VR**: reference value according to Kaneko et al. (2008).

The losses of nitrogen via urine corresponded to $21.58 \%$ of the total ingested. This indicates that the increase in ingested $\mathrm{N}$ resulted in nitrogen over the rumen, causing the animal to concentrate its elimination through urine, thus avoiding possible ammonia poisoning. This mechanism results in higher energy expenditure by the liver since the synthesis of urea from ammonia is an energyintensive process, and is estimated in sheep to require approximately $88.4 \mathrm{kcal} \mathrm{mol}^{-1}$ (MARTIN; BLAXTER, 1965). Moreno et al. (2010) found losses of 40.74 and $22.20 \%$ for faecal and urinary $\mathrm{N}$, respectively.
The nitrogen balance (NB) presented a positive linear equation in response to the inclusion of amino acids in the diet (Table 3 ). The fact that the $\mathrm{BN}$ was positive indicates that the animals did not need to mobilise body protein reserves to meet their nutritional requirements. According to Zeoula et al. (2006), the higher NB values in diets with a high concentrate content might be due to the higher $\mathrm{CP}$ intake and digestibility. In fact, in the present study, it was observed that the animals that received higher levels of protected lysine and methionine had higher DMI and NB values (Tables 2 and 3). 
In view of the above, the inclusion of protected lysine and methionine in the diet of lambs up to 32 $\mathrm{g}$ increases the DMI without negatively affecting its digestibility, in addition to increasing nitrogen intake. The excess of dietary $\mathrm{N}$ resulted in an increase in its excretion via urine, which might have caused an increase in the energetic expenditure by the animals.

The different levels of protected amino acids did not influence the blood protein profile of the animals (Tables 4). Among all the protein metabolites evaluated, only creatinine and urea were outside of the reference values. These variables are directly related to the results discussed above.

Urea is a sensitive and immediate indicator of protein intake and is synthesised in amounts proportional to the concentration of ammonia produced in the rumen (WITTWER, 2000), the latter being toxic to ruminants when present in high concentrations. It is noteworthy that even though there was no difference between treatments, all the treatments had serum urea concentrations averaging $5.8 \%$ above the reference limit (Table 4). This might imply a higher production of ammonia in the rumen and an increase in ammonia in the ruminal wall, resulting in a higher conversion of ammonia to urea in the liver, which might result in nitrogen wastage in the ruminal environment and a higher energy expenditure by the liver, given that the synthesis of urea from ammonia is an energetically expensive process and there is a cost for the excretion of urea by the kidneys (MARTIN; BLAXTER, 1965).

Approximately $60 \%$ to $80 \%$ of the protein is transformed into ammonia in the rumen, which is used by ruminal microorganisms for the synthesis of other compounds, and the surplus is absorbed and transported to the liver where it is converted into urea and excreted via faeces and urine. A fraction is returned to the rumen through saliva (WITTWER, 2000). In fact, it was observed that a high DMI and ingested $\mathrm{N}$ (Table 2 and 3 ) resulted in excess ammonia, which in turn was converted to urea, indicated by its increase in the blood (Table 4). Consequently, this increase in urea caused more excretion of urinary $\mathrm{N}$ (Table 3) as a way to avoid intoxication.

The creatinine level was on average $47.5 \%$ below the minimum reference value, which is 1.2 $\mathrm{mg} \mathrm{dL}{ }^{-1}$. This metabolite is formed in the muscle by the irreversible and non-enzymatic removal of water from creatine phosphate, which in turn originates from amino acid metabolism (HARPER et al., 1982). In addition, it has a close relationship with muscle mass that varies according to the degree of exercise performed by the animals. Since the animals were kept in metabolic cages and did not perform activities such as walking or grazing, among others, this explains the low creatinine values. Since the blood levels of creatinine are little affected by diet, creatinine is used as a reference to correct for variations in blood urea (GONZÁLEZ et al., 2000).

Uric acid correlates with the amount of microbial protein available for intestinal digestion by the animal, and its values were within the indicated range (Table 4). The high CP content of the diet associated with the increase in nitrogen consumption (Tables 1, 2, and 3) did not influence the values of uric acid obtained. The serum globulin concentration remained within the reference value range (Table 4). The globulins are the main plasma proteins, performing a variety of functions: maintenance of osmotic pressure and blood viscosity; transport of nutrients, metabolites, hormones, and excretion products; regulation of blood $\mathrm{pH}$; and blood coagulation (GONZÁLEZ; SILVA, 2006).

The total protein and albumin levels remained within the maximum limit of the reference values. These metabolites are directly related to the dietary protein concentration, are synthesised mainly in the liver, and the amount produced indicates the nutritional state of the animal (WITTWER, 2000). Therefore, the results obtained are a consequence of the high protein intake of the diets (Table 1), which also explains the blood urea concentration (Table 4). 
It was observed that the higher the inclusion level of protected amino acids in the diet, the higher the concentration of protein metabolites in the blood, however, the excess protein from the diet causes losses of urinary nitrogen with a possible energy expenditure, which might hinder production.

\section{Conclusion}

The amino acids lysine and methionine, when protected from ruminal degradation, can be included at a level of up to $32 \mathrm{~g}$ in the diet of growing ewes, and increase the consumption of dry matter without negatively affecting digestibility and without damaging protein metabolism.

\section{References}

ALVES, D. Nutrição aminoacídica de bovinos. Revista Brasileira de Agrociência, Pelotas, v. 10, n. 3, p. 265271, 2004. DOI: 10.18539/cast.v10i3.956

ANTONGIOVANNI, M.; ACCIAIOLI, A.; FRANCI, O.; PONZETTA, M. P.; PUGLIESE, C.; BUCCIONI, A.; BADII, M. Field bean (Vicia faba var. minor) as a protein feed for growing lambs with and without protected lysine and methionine supplementation. Italian Journal of Animal Science, Bologna, v. 1, n. 1, p. 229-238, 2002. DOI: 10.4081/ijas.2002.229

BERCHIELLI, T. T.; PIRES, A. V.; OLIVEIRA, S. G. Nutrição de ruminantes. Jaboticabal: Funep, 2006. 583 p.

CONTRERAS, P.; WITTWER, F.; BÖHMWALD, H. Uso dos perfís metabólicos no monitoramento nutricional dos ovinos. In: GONZÁLEZ, F. H. D.; BARCELLOS, J. O.; OSPINA, H.; RIBEIRO, L. A. O. (Ed.). Perfil metabólico em ruminantes: seu uso em nutrição e doenças nuricionais. Porto Alegre: Gráfica da Universidade Federal do Rio Grande do Sul, 2000. p. 75-88.

GERON, L. J. V.; COSTA, F. G.; SANTOS, R. H. E.; GARCIA, J.; MACHADO, R. J. T.; SILVA, M. I. L.; ZEOULA, L. M.; SILVA, D. A. Balanço de nitrogênio em cordeiros alimentados com rações contendo diferentes teores de concentrado. Semina: Ciências Agrárias, Londrina, v. 36, n. 3, p. 1609-1622, 2015. DOI: 10.5433/1679-0359.2015v36n3p1609

GONZÁLEZ, F. H. D.; CONCEIÇÃO, T. R.; SIQUEIRA, A. J. S.; LA ROSA, V. L. Variações sanguíneas de ureia, creatinina, albumina e fósforo em bovinos de corte no
Rio Grande do Sul. A Hora Veterinária, Porto Alegre, v. 20, n. 1, p. 59-62, 2000.

GONZÁlEZ, F. H. D.; SILVA, S. C. Introdução à bioquímica clínica veterinária. Porto Alegre: Gráfica da Universidade Federal do Rio Grande do Sul, 2006.357 p.

GUIMARÃES JÚNIOR, R.; GONÇALVES， L. C.; PEREIRA, L. G. R.; PIRES, D. A. de A.; RODRIGUES, J. A. S.; MIRANDA, K. L.; ARAÚJO, V. L. Balanço de nitrogênio em ovinos alimentados com silagens de três genótipos de milheto Pennisetum glaucum (L.) R. Br. In: REUNIÃO ANUAL DA SOCIEDADE BRASILEIRA DE ZOOTECNIA, 44., 2007, Jaboticabal. Anais... Jaboticabal: SBZ, 2007. 1 CD-ROM.

HAN, I. K.; HA, J. K.; LEE, S. S.; KO, Y. G.; LEE, H. S. Effect of supplementing rúmen-protected lysine and methionine on ruminal 21 characteristics and nutrient digestibility in sheep. Asian-Australasian Journal of Animal Sciences, Seoul, v. 9, n. 2, p. 223-229, 1996. DOI: 10.5713/ajas.1996.223

HARPER, H. A.; RODWELL, V. W.; MAYES, P. A. Manual de química fisiológica. 5. ed. São Paulo: Atheneu. $1982.736 \mathrm{p}$.

KANEKO, J. J.; HARVEY, J. W.; BRUSS, M. L. Clinical biochemistry of domestic animals. 6. ed. San Diego: Academic Press. 2008. 916 p.

MARTIN, A. K.; BLAXTER, K. L. The energy cost of urea synthesis in sheep. In: BLAXTER, K. L. (Ed.). Energy metabolism. London: Academic Press, 1965. p. 83-91.

MAYNARD, L. A.; LOOSLI, B. S.; HINTZ, H. F.; WARNER, R. G. Nutrição animal. 3. ed. Rio de Janeiro: Freitas Bastos, 1984. 726 p.

MERTENS, D. R. Regulation of forage intake. In: FAHEY JUNIOR, G. C. (Ed.). Forage quality, evaluation and utilization. Madison: American Society of Agronomy, 1994. p. 450-493.

MORENO, G. M. B.; SOBRINHO, A. G. S.; LEÃO, A. G.; LOUREIRO, C. M. B.; PEREZ, H. L.; ROSSI, R. C. Desempenho, digestibilidade e balanço de nitrogênio em cordeiros alimentados com silagem de milho ou cana-deaçúcar e dois níveis de concentrado. Revista Brasileira de Zootecnia, Brasília, v. 39, n. 4, p. 853-860, 2010. DOI: $10.1590 / \mathrm{S} 1516-35982010000400022$

NATIONAL RESEARCH COUNCIL - NRC. Nutrient requirements of small ruminants. Washington, D. C: National Academy Press, 2007. 384 p.

NATIONAL RESEARCH COUNCIL - NRC. Ruminant nitrogen usage. Washington: National Academy Press, 1985. $138 \mathrm{p}$. 
POLAN, C. E. Dietary protein and microbial protein contribution. Journal of Nutrition, Pennsylvania, v. 18, n. 2, p. 242-248, 1988. DOI: 10.1093/jn/118.2.242

RIBEIRO, K. G.; GARCIA, R.; PEREIRA, O. G.; VALADARES FILHO, S. de C.; CECON, P. R. Eficiência microbiana, fluxo de compostos nitrogenados no abomaso, amônia e $\mathrm{pH}$ ruminais em bovinos recebendo dietas contendo feno de capim-Tifton 85 de diferentes idades de rebrota. Revista Brasileira de Zootecnia, Brasília, v. 30, n. 2, p. 581-588, 2001. DOI: 10.1590/ S1516-35982001000200038

SANTOS, F. A. P.; MACEDO, F. L.; CHAGAS, L. J. Aplicação do conceito de proteína ideal para bovinos leiteiros. In: SIMPÓSIO NACIONAL DE BOVINOCULTURA DE LEITE, 3., 2017, Viçosa, MG. Anais... Viçosa, MG: Universidade Federal de Viçosa, 2017. p. 301-334.

SCHWAB, C. G.; BOUCHER, S. E.; SLOAN, B. K. Metabolizable protein and amino acid nutrition of the cow: Where are we in 2007. In: ANNUAL MINNESOTA
NUTRITION CONFERENCE, 68., 2007, Minnesota. Proceedings... Minnesota, 2007. p. 121-138.

SILVA, D. J.; QUEIROZ, A. C. de. Análise de alimentos: métodos químicos e biológicos. Viçosa, MG: UFV, 2002. $235 \mathrm{p}$.

WITTWER, F. Diagnóstico dos desequilíbrios metabólicos de energia em rebanhos bovinos. In: GONZÁLEZ, F. H. D.; BARCELLOS, J. O.; OSPINA, H.; RIBEIRO, L. A. O. (Ed.). Perfil metabólico em ruminantes: seu uso em nutrição e doenças nutricionais. Porto Alegre: Gráfica da Universidade Federal do Rio Grande do Sul, 2000. p. 9-22.

ZEOULA, L. M.; FERELI, F.; PRADO, I. N.; GERON, L. J. V.; CALDAS NETO, S. F.; PRADO, O. P. P. P.; MAEDA, E. M. Digestibilidade e balanço de nitrogênio de rações com diferentes teores de proteína degradável no rúmen e milho moído como fonte de amido em ovinos. Revista Brasileira de Zootecnia, Brasília, v. 35, n. 5, p. 2179-2186, 2006. DOI: 10.1590/S151635982006000700039 